\title{
Alterations in the fatty acid profile, antioxidant enzymes and protein pattern of Biomphalaria alexandrina snails exposed to the pesticides diazinon and profenofos
}

\author{
Fayez A. Bakry ${ }^{1}$, Karem El-Hommossany ${ }^{1}$, M. S. Abd El-Atti ${ }^{3}$ and Somaya M. Ismail ${ }^{2}$ \\ ${ }^{1}$ Medical Malacology Department, Theodor Bilharz Research Institute, Egypt. \\ ${ }^{2}$ Zoology Department, Faculty of Science, Cairo University, Egypt. \\ ${ }^{3}$ Department of Zoology, Faculty of Science, Zagazig University, Egypt.
}

Accepted 22 March, 2013

\begin{abstract}
The use of pesticides is widespread in agricultural activities. These pesticides may contaminate the irrigation and drainage systems during agricultural activities and pests' control and then negatively affect the biotic and abiotic component of the polluted water courses. The present study aimed to evaluate the effect of the pesticides diazinon and profenofos on some biological activities of Biomphalaria alexandrina snails such as fatty acid profile, some antioxidant enzymes like thioredoxin reductase (TrxR), sorbitol dehydrogenase (SDH), superoxide dismutase (SOD), catalase (CAT) as well as glutathione reductase (GR) and lipid peroxidation (LP) and protein patterns in snails' tissues exposed for 4 weeks to $L C_{10}$ of diazinon and profenofos. The results showed that the two pesticides caused considerable reduction in survival rates and egg production of treated snails. Identification of fatty acids composition in snails' tissues treated with diazinon and profenofos pesticides was carried out using gas liquid chromatography (GLC). The results declared alteration in fatty acid profile, fluctuation in percent of long chain and short chain fatty acid contributions either saturated or unsaturated ones and a decrease in total lipid content in tissues of snails treated with these pesticides. The data demonstrate that, there was a significant inhibition in the activities of tissues SOD, CAT, GR, TrxR and SDH in tissues of treated snails while a significant elevation was detected in lipid peroxidation as compared to the normal control. On the other hand, the electrophoretic pattern of total protein showed differences in number and molecular weights of protein bands due to snails' treatment. It was concluded that the residues of diazinon and profenofos pesticides in aquatic environments have toxic effects on $B$. alexandrina snails.
\end{abstract}

Key words: Snails, pesticides, antioxidants, enzymes, fatty acids, proteins, biochemistry.

\section{INTRODUCTION}

Pesticides are ubiquitous contaminants of the environment and have been found in samples from air, soil, water, and human and animal tissues all over the world. These cover a wide range of compounds used in pest control, such as fungicides, herbicides, molluscicides, insecticides, rodenticides and others (Bakry et al., 2011; Nasri et al., 2012).

The use of pesticides may engender biological effects beyond those for which they were originally manufactured (Al-Saleh, 1994). Agricultural insecticides may interfere 
in the life, reproduction and infection of snail vectors of schistosomiasis when they reach water bodies (Rawi et al., 1994; Asgarpanah and Ramezanloo, 2012). Pesticides may play an important role in the disappearance of snail vectors on reaching water bodies as residues from pesticide activities and consequently hindering schistosomiasis transmission in these sites (Abdel Kader and Sharaf El-Din, 2005).

Diazinon and profenofos are among the currently used organophosphorus pesticides in agricultural activities. They inhibit the activity of acetylcholinesterase (ChE) which is important for nervous system functions (Van Cong et al., 2006). Diazinon was highly toxic to the snakehead fish (Channa striata) in the Mekong River Delta, Vietnam, with a 96-h median lethal concentration $\left(\mathrm{LC}_{50}\right)$ of $0.79 \mathrm{mg} / \mathrm{L}$, and caused long-term ChE inhibition (Alahyary et al., 2008). In rats, diazinon intraperitoneal administration damaged their testis germinal epithelium leading to spermatogenesis failure after $36 \mathrm{~h}$, then infertility can appear (Cabaj et al., 2010). Profenofos is moderately toxic to birds and has low mammalian toxicity with good insecticidal properties (Tomlin, 1997). Also, it induced apoptosis and necrosis in cultured human peripheral blood lymphocytes under in vitro conditions using the DNA diffusion assay (Das et al., 2006; Alam et al., 2012).The present study aims to evaluate the impact of the pesticides Basudin and Selecron against some biological activities of Biomphalaria alexandrina snails, in addition to the fatty acid profile, antioxidant enzymes and protein pattern in their tissues.

\section{MATERIALS AND METHODS}

Snails

B. alexandrina snails ( 6 to $8 \mathrm{~mm}$ ) from laboratory bred colony in Medical Malacology Department, Theodor Bilharz Research Institute (TBRI) were used. The snails were daily fed oven dried lettuce leaves and blue-green algae (Nostoc muscorum).

\section{Tested pesticides}

Diazinon (Basudin, 62\% E.C.) is an organophosphorus insecticide O,O-diethyl O-[6-methyl-2-(1-methylethyl)-4-pyrimidinyl] phosphorothioate, while profenofos (Selecron, 72\% E.C.) is an organophosphorus insecticide, O-4-bromo-2-chlorophenyl O-ethyl S-propyl phosphorothioate. Diazinon and profenofos were from the Plants Protection Center, Ministry of Agriculture, Dokki, Giza, Egypt (Figure 1).

\section{Bioassay tests}

\section{Molluscicidal screening}

A stock solution of $500 \mathrm{ppm}$ was prepared from each pesticide (diazinon and profenofos) on the basis of $\mathrm{V} / \mathrm{V}$ using dechlorinated tap water $(\mathrm{pH} 7.0$ to 7.5$)$. A series of concentrations $(0.5,1,1.5,2$, 2.5, 3 and $4 \mathrm{ppm}$ ) that would permit the computation of $\mathrm{LC}_{50}$ and

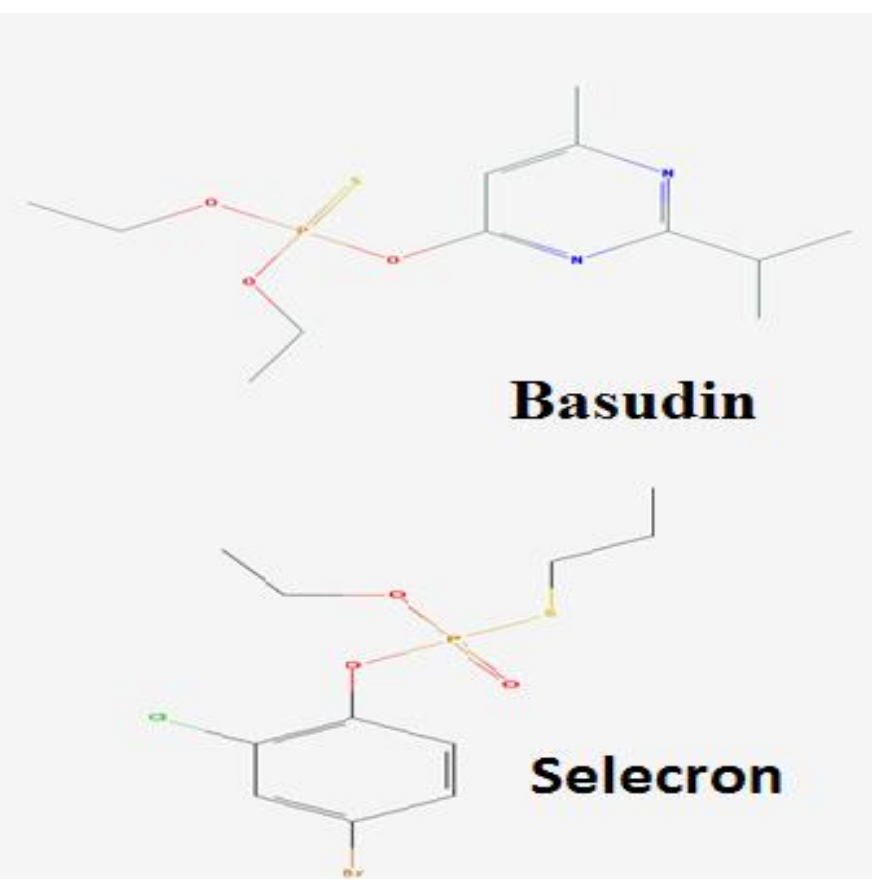

Figure 1. Chemical structure of pesticides of Basudin and Selecron.

LC $_{90}$ values were prepared from each compound (WHO, 1965). Three replicates per each concentration and control were used $(10$ snails/L). Exposure period was $24 \mathrm{~h}$ each at $25 \pm 1^{\circ} \mathrm{C}$. The effectiveness for each pesticide has been expressed in terms of $\mathrm{LC}_{50}$ and $\mathrm{LC}_{90}$ (Litchfield and WiLcoxon, 1949).

Effect of prolonged exposure to the two pesticides on snails' egg-laying capacity and survival rate of $B$. alexandrina

B. alexandrina snails ( 6 to $8 \mathrm{~mm}$ ) were continuously exposed for 4 weeks to $\mathrm{LC}_{5}$ and $\mathrm{LC}_{10}$ of diazinon (1.40 and $\left.1.90 \mathrm{ppm}\right)$ and profenofos (0.64 and $0.75 \mathrm{ppm})$ pesticide, respectively. Fresh concentrations were weekly prepared. Three replicates, each of 10 snails/L, were prepared for each concentration, another three of the control snails were maintained in dechlorinated water $\left(25 \pm 1^{\circ} \mathrm{C}\right)$. Each aquarium was provided with one piece of polyethylene sheet for oviposition (Pellegrino and Goncalves, 1965). The eggs lay on these sheets and on the wall of the aquaria were weekly counted using a stereomicroscope and a hand lens. Dead snails were removed from the aquaria and the number of alive ones at the end of each week was recorded. The parameters used to express the efficiency of the tested compounds are $L_{x}$, that refers to survival ship or the ratio of surviving snails in each week as a fraction of the correct one $(1.0=100 \%)$, Mx represents the egg laying capacity or the mean number of eggs per snail per week, $L_{x} M_{x}$ refers to the product of $L_{x} \times M_{x}$ in each week and the $R_{0}$ is the reproductive rate at the end of the experiment $\left(\sum L_{x} M_{x}\right)$.

\section{Biochemical parameters}

The present experiment aimed to determine protein pattern and the activities of some antioxidant enzymes in tissues of $B$. alexandrina snails treated with the experimental pesticides. Adult snails ( 8 to 10 $\mathrm{mm}$ ) were continuously exposed for 4 weeks to $\mathrm{LC}_{10}$ of diazinon 
Table 1. Molluscicidal activity of the Basudin and Selecron pesticides against Biomphalaria alexandrina snails.

\begin{tabular}{lccccccc}
\hline Pesticide & $\mathbf{L C}_{0}(\mathbf{p p m})$ & $\mathbf{L C}(\mathbf{p p m})$ & $\mathbf{L C}_{10}(\mathbf{p p m})$ & $\mathbf{L C}_{25}(\mathbf{p p m})$ & $\mathbf{L C}_{50}(\mathbf{p p m})$ & $\mathbf{L C}_{90}(\mathbf{p p m})$ & Slope \\
\hline Basudin & 0.46 & 1.40 & 1.90 & 2.30 & 3.10 & 4.90 & 1.60 \\
Selecron & 0.21 & 0.64 & 0.75 & 0.91 & 1.10 & 1.50 & 1.30 \\
\hline
\end{tabular}

(1.90 ppm) and profenofos (0.75 ppm) pesticide. Fresh concentrations were weekly prepared. The snails were fed oven dried lettuce leaves and dead ones were daily removed. The survived snails, after that, were washed thoroughly with water, their soft parts were dissected out from their shells, weighed and homogenized in cold distilled water $(\mathrm{pH}$ 7.5) at $1 \mathrm{~g}: 10 \mathrm{ml}(\mathrm{w} / \mathrm{v})$ using a glass homogenizer for $5 \mathrm{~min}$. The homogenates were centrifuged $15 \mathrm{~min}$ at $3000 \mathrm{rpm}$ at $4^{\circ} \mathrm{C}$ and the fresh supernatant was used to determine the protein pattern (Marchat et al., 1994; Laemmli, 1970) and activities of the antioxidant enzymes glutathione reductase (Erden and Bor, 1984). Catalase (Monhanty et al., 1997), superoxide dismutase (Nishikimi et al., 1972), lipid peroxidation (Buge and Aust, 1978), sorbitol dehydrogenase (Bergmeryer, 1974) and thioredoxin reductase (Arnér and Holmgren, 2000). Kits for enzymes assay were bought from Quimica Clinica Aplicada S. A. (QCA) Ltd.

\section{Fatty acid profile}

The whole soft tissues of treated snails with $\mathrm{LC}_{10}$ of diazinon and profenofos, respectively and control ones were subjected for evaluating the fatty acid (Higgs and Sherma, 1990).

\section{Isolation of native lipids}

Lipids were extracted from snails tissues with 10 to $14 \mathrm{ml}$ of chloroform-methanol (2:1). The extracts were filtered through a plug of glass wool contained in a pasture pipette and non-lipid contaminants were removed by extraction with 8 to $10 \mathrm{ml}$ of Folch wash $(0.88 \%$ aqueous $\mathrm{KCl}$ solution). The lipid-containing lower phase separated and evaporated just to dryness under a stream of nitrogen at room temperature. The total lipid sample was dissolved in approximately $30 \mathrm{ml}$ methanol and 0.5 to $1.0 \mathrm{ml}$ concentrated sulfuric acid was added. The mixture was refluxed for $1 \mathrm{~h}$, the formed fatty acid methyl esters was extracted with 30 to $40 \mathrm{ml}$ petroleum ether $\left(40\right.$ to $\left.60^{\circ} \dot{\mathrm{C}}\right)$, and the extract dried over anhydrous sodium sulfate. The fatty acid methyl esters were concentrated in a Rotor evaporator at $40^{\circ} \mathrm{C}$ and the volume was reduced to $1 \mathrm{ml}$. One microlitre of each concentrated test solution was injected into gas chromatography (GLC) using a $10 \mu \mathrm{l}$ syringe (Fried et al., 1991). GLC analysis was performed in the National Research Center (Unit of central services) Dokki, Cairo, Egypt.

\section{Lipid analysis by GLC}

The GLC analysis of fatty acid methyl esters was carried out using a Hewlett-Packard Model 5890-A gas chromatograph fitted with a polar (Supelcowax $\left.\mathrm{TM}_{10}\right)$ fused silica capillary column $(30 \mathrm{~m} \times 0.32$ $\mathrm{mm}$ ) (Supelco, Inc., Bellefonte, PA), flame ionization detector, and data processor. The helium carrier gas was used at a pressure of 12 psig, and the injection port, column, and detector temperatures were maintained at 220,210 and $220^{\circ} \mathrm{C}$, respectively. GLC peaks were identified by comparison with the retention times of fatty acid methyl ester standards (obtained from Sigma Chemical Co., USA) and cold liver oil fatty acid methyl esters.
Identification of peaks by GLC representing lipids with different numbers of double bonds was confirmed by comparison of the $R_{F}$ values of standard and samples separated by argentation thin layer chromatography (TLC) (Morris, 1962). Silica gel layers containing $9 \%(\mathrm{w} / \mathrm{w})$ silver nitrate were developed with diethyl ether-hexane (1:9) mobile phase, and lipid zones were detected by spraying the plate with 2,7-dichlorofluorescein and inspection under 254 and 366 $\mathrm{nm}$ ultraviolet (UV) light. Quantitative results were determined by area normalization, in which the percentage of each component was calculated from the percent of the total area represented. Total lipid of control and treated snails were estimated according to the method of Zollner and Kirsch (1962).

\section{Statistical analysis}

Values of biochemical result were expressed as a mean \pm standard error (SE). The obtained data were statistically analyzed for the significance of differences between treated and control groups using student "t" test (Goldstein, 1964).

To calculate percentage band in protein pattern sharing, the bands observed in a given lane were compared with those in other lanes of the same gel. Enlarged photographs of the gels with bands of snails' protein pattern were examined and the principal bands were scored. A similarity matrix was constructed on the basis of the presence/absence of bands between all possible pairs in an analysis group using the Dice similarity coefficient (Dice, 1945) using the formula: $S=2 a / 2 a+b+c$; where $a$ is the number of bands shared between organisms 1 and $2, b$ is the number of bands present in 1 but not in 2 and $c$ is the number of bands present in 2 but not in 1 . Fatty acid profile was analyzed by one way analysis of variance with Costat Computer Program.

\section{RESULTS}

From the present data (Table 1), it was noticed that, $\mathrm{LC}_{90}$ values of the diazinon and profenofos were 4.9 and 1.5 ppm, respectively against $B$. alexandrina snails after $24 \mathrm{~h}$ of exposure. It is seen, also, that profenofos as a pesticide was more toxic to $B$. alexandrina snails than diazinon by about three folds.

As shown in Table 2, the survival rates $\left(L_{x}\right)$ of snails exposed to $L_{10}$ of profenofos or diazinon were sharply suppressed throughout the experimental period (4 weeks). Thus, $L_{x}$ values of these snail groups were 0.2 (20\% survival rate) post 3 weeks of exposure, compared to $100 \%$ survival rate for control group $\left(L_{x}=1.0\right)$. Moreover, no snail could survive at the tested concentrations by the 4 th week ( $100 \%$ death).

For snails' fecundity $\left(M_{x}\right)$, it was highly reduced for snails exposed to these pesticides, as the number of eggs/snail/week at the 3rd week of the experiment was 0.2 and 0.5 eggs for snails exposed to $\mathrm{LC}_{5}$ from diazinon 
Table 2. Survival rate $(\mathrm{Lx})$ and fecundity $(\mathrm{Mx})$ of Biomphalaria alexandrina snails after 4 weeks of continuous exposure to sublethal concentrations of Basudin and Selecron.

\begin{tabular}{|c|c|c|c|c|c|c|c|c|c|c|c|c|c|c|c|}
\hline \multirow{3}{*}{\multicolumn{2}{|c|}{$\begin{array}{l}\text { Concentration } \\
\text { (ppm) }\end{array}$}} & \multicolumn{12}{|c|}{ Observation period (week, $\mathbf{x}$ ) } & \multirow{3}{*}{$\begin{array}{c}\text { Ro } \sum \text { LxMx } \\
\text { (reproductive } \\
\text { rate) }\end{array}$} & \multirow{3}{*}{$\begin{array}{c}\text { Reduction of } \\
\text { Ro (\%) }\end{array}$} \\
\hline & & \multicolumn{3}{|c|}{1} & \multicolumn{3}{|c|}{2} & \multicolumn{3}{|c|}{3} & \multicolumn{3}{|c|}{4} & & \\
\hline & & $\mathbf{L x}$ & Mx & LxMx & $\mathbf{L x}$ & Mx & LxMx & $\mathbf{L x}$ & $\mathbf{M x}$ & LxMx & $\mathbf{L x}$ & Mx & LxMx & & \\
\hline Control & & 1.0 & 8.5 & 8.5 & 1.0 & 5.0 & 5.0 & 1.0 & 10 & 10.0 & 1.0 & 6.0 & 6.0 & 29.5 & - \\
\hline Basudin & $\begin{array}{c}0.46 \\
1.4\end{array}$ & $\begin{array}{l}1.0 \\
1.0\end{array}$ & $\begin{array}{l}0.0 \\
0.0\end{array}$ & $\begin{array}{l}0.0 \\
0.0\end{array}$ & $\begin{array}{l}0.6 \\
0.5\end{array}$ & $\begin{array}{l}1.5 \\
1.0\end{array}$ & $\begin{array}{l}0.9 \\
0.5\end{array}$ & $\begin{array}{l}0.4 \\
0.2\end{array}$ & $\begin{array}{l}0.5 \\
1.0\end{array}$ & $\begin{array}{l}0.2 \\
0.2\end{array}$ & $\begin{array}{l}0.0 \\
0.0\end{array}$ & $\begin{array}{l}0.0 \\
0.0\end{array}$ & $\begin{array}{l}0.0 \\
0.0\end{array}$ & $\begin{array}{r}1.1 \\
0.7\end{array}$ & $\begin{array}{l}96.27 \\
97.63\end{array}$ \\
\hline Selecron & $\begin{array}{l}0.75 \\
0.91\end{array}$ & $\begin{array}{l}1.0 \\
1.0\end{array}$ & $\begin{array}{l}1.0 \\
0.0\end{array}$ & $\begin{array}{l}1.0 \\
0.0\end{array}$ & $\begin{array}{l}0.5 \\
0.4\end{array}$ & $\begin{array}{l}0.0 \\
0.0\end{array}$ & $\begin{array}{l}0.0 \\
0.0\end{array}$ & $\begin{array}{l}0.5 \\
0.2\end{array}$ & $\begin{array}{l}1.0 \\
0.5\end{array}$ & $\begin{array}{l}0.5 \\
1.0\end{array}$ & $\begin{array}{l}0.0 \\
0.0\end{array}$ & $\begin{array}{l}0.0 \\
0.0\end{array}$ & $\begin{array}{l}0.0 \\
0.0\end{array}$ & $\begin{array}{l}1.5 \\
1.0\end{array}$ & $\begin{array}{l}94.92 \\
96.61\end{array}$ \\
\hline
\end{tabular}

and profenofos, respectively, compared to 10 eggs/control snail. Moreover, treated snails ceased egg-laying at the 4th week of the experiment. Therefore, the reproductive rate $\left(R_{0}\right)$ of treated snails was highly reduced from that of the control group. The reduction rates in this parameter $\left(\mathrm{R}_{0}\right)$ for snails treated with these pesticides were $>94 \%$, which means that the population size of such treated snails will be minimized; consequently hindering schistosomiasis transmission is expected.

The pattern of protein profile identified by sodium dodecyl sulfate polyacrylamide gel electrophoresis (SDS-PAGE) for tissues of $B$. alexandrina snails exposed to diazinon and profenofos pesticides is as shown in Figure 3 . Data in Tables 3 and 4 as well as in Figure 3 show that the protein profile of untreated $B$. alexandrina composed of 16 protein bands. This profile reduced to 13 and 11 bands after treatment of $B$. alexandrina with diazinon and profenofos, respectively. The molecular weights of these bands for snails treated with diazinon ranged from 113.3 to $25.06 \mathrm{KDa}$ and those for profenofos treatment ranged from 114.58 to $27 \mathrm{KDa}$.

Table 3 and Figure 3 show the appearance of bands in treated snail groups and disappearance of others in comparison with control group. For snails treated with diazinon, 10 bands disappeared (116.75, 105.75, 102.63, 93.84, 80.50, $53.68,47.18,44.16,38.41$ and $27.5 \mathrm{KDa}$ ), while 9 bands appeared (113.3, 90, 61.22, 50.76, 46.58, 42.49, 37.98, 27 and 25.06 KDa). Similar pattern was recorded for snails treated with profenofos as 8 bands appeared (114.58, 90, 82.68, 50.76 43.36, 39.73, 36.10 and $27 \mathrm{KDa}$ ). There are four shared bands $(72.53,56.04,36.10$ and 30.87 $\mathrm{KDa}$ ) that appeared in protein profile of the contro and snails treated with diazinon, while three shared band (69.25, 56.04 and $40.49 \mathrm{KDa}$ ) appeared in protein profile of the control and snails treated with profenofos. The shared bands seemed not to be affected by the pesticides in spite of the variation shown in their percentage of protein. The present results showed qualitative and quantitative differences in protein pattern between treated and control snails.

The current results (Table 4) indicated that the similarity index (S) was higher in the case of snails treated with diazinon than those treated with profenofos $(0.28$ and 0.22 , respectively) indicating that profenofos had strong effect than diazinon on protein profile of soft tissues of snails. Results listed in the Table 5 and Figure 2 showed that the data demonstrate that, there was a significant inhibition in SOD, CAT, GR, TrxR, SDH and a significant elevation in lipid peroxidation (LP) in treated snails as compared to the normal snails. The inhibition of enzymes activities in tissues of snails treated with the pesticide profenofos was higher than that of diazinon treatment. So, the percentages of inhibition for the enzymes GR, TrxR and SDH in profenofos treatment were $61.36,72.92$ and $72.9 \%$, respectively, as compared to $50,54.17$ and $35.48 \%$ in diazinon treatment. On the other hand, the activity of LP was elevated by 23.69 and55.77\% in tissues of snails treated with diazinon and profenofos, respectively.

Results presented in Table 6 showed the area percentage of fatty acid compositions which are the major components of the total lipid isolated from tissue homogenates of $B$. alexandrina treated with diazinon and profenofos pesticides. It can easily be noticed that free fatty acid (FFA) composition in snails' tissues varies between two pesticides treatment. About 15 different fatty acids were consistently detected in $B$. alexandrina 
Table 3. Tissues protein fractionation of Biomphalaria alexandrina snails treated for 4 weeks with Basudin and Selecron (pesticides).

\begin{tabular}{|c|c|c|c|c|c|c|c|}
\hline \multicolumn{2}{|c|}{ Marker (KDa) } & \multicolumn{2}{|c|}{ Control } & \multicolumn{2}{|c|}{ Basudin (1.9 ppm) } & \multicolumn{2}{|c|}{ Selecron (0.75 ppm) } \\
\hline KD & $\%$ & KD & $\%$ & KD & $\%$ & KD & $\%$ \\
\hline- & - & 116.75 & 8.62 & - & - & - & - \\
\hline 116 & 12.2 & - & - & - & - & - & - \\
\hline - & - & - & - & - & - & 114.58 & 1.4 \\
\hline - & - & - & - & 113.3 & 1.4 & - & - \\
\hline - & - & 105.75 & 2.05 & - & - & - & - \\
\hline - & - & 102.63 & 2.07 & - & - & - & - \\
\hline - & - & 93.84 & 2.86 & - & - & - & - \\
\hline 90 & 13.7 & - & - & 90 & 10.2 & 90 & 14.3 \\
\hline- & - & 80.50 & 14.2 & - & - & - & - \\
\hline- & - & - & - & - & - & 82.68 & 3.77 \\
\hline - & - & 72.53 & 3.50 & 72.53 & 10.10 & - & - \\
\hline- & - & 69.25 & 4.55 & - & - & 69.25 & 15.55 \\
\hline- & - & - & - & 61.22 & 2.10 & - & - \\
\hline 58 & 20.7 & - & - & - & - & - & - \\
\hline- & - & 56.04 & 13.3 & 56.04 & 3.63 & 56.04 & 15.11 \\
\hline - & - & 53.68 & $7.1^{`}$ & - & - & - & - \\
\hline - & - & - & - & 50.76 & 10.72 & 50.76 & 7.71 \\
\hline - & - & 47.18 & 13.40 & - & - & - & - \\
\hline - & - & - & - & 46.58 & 3.84 & - & - \\
\hline 45 & 19.5 & - & - & - & - & - & - \\
\hline - & - & 44.16 & 1.81 & - & - & - & - \\
\hline- & - & - & - & - & - & 43.36 & 5.5 \\
\hline - & - & - & - & 42.49 & 3.34 & - & - \\
\hline - & - & 40.49 & 5.34 & - & - & 40.49 & 5.34 \\
\hline- & - & - & - & - & - & 39.73 & 15.26 \\
\hline - & - & 38.41 & 2.67 & - & - & - & - \\
\hline - & - & - & & 37.98 & 14.06 & - & - \\
\hline 36.5 & 9.20 & - & - & - & - & - & - \\
\hline - & - & 36.10 & 2.52 & 36.10 & 12.02 & - & - \\
\hline - & - & - & - & - & - & 36.10 & 2.86 \\
\hline - & - & 30.87 & 5.46 & 30.87 & 2.46 & - & - \\
\hline - & - & 27.5 & 10.35 & - & - & - & - \\
\hline - & - & - & - & 27 & 12.2 & 27 & 13.2 \\
\hline 26.6 & 24.1 & - & - & - & - & - & - \\
\hline- & - & - & - & 25.06 & 13.93 & - & - \\
\hline Sum in lane & 100 & - & 100 & - & 100 & - & 100 \\
\hline Bands & - & 16 & - & 13 & - & 11 & - \\
\hline
\end{tabular}

species. In general the major component of the FFA fraction were $\mathrm{C}_{15: 0}, \mathrm{C}_{16: 0}, \mathrm{C}_{16: 1}, \mathrm{C}_{17: 0}, \mathrm{C}_{18: 1}, \mathrm{C}_{18: 2}, \mathrm{C}_{18: 3}$ and $\mathrm{C}_{20: 0 .}$. It was shown that, control snails have ten saturated fatty acids: $\mathrm{C}_{8}, \mathrm{C}_{9}, \mathrm{C}_{10}, \mathrm{C}_{12}, \mathrm{C}_{14}, \mathrm{C}_{15}, \mathrm{C}_{16}, \mathrm{C}_{17}, \mathrm{C}_{18}$ and $\mathrm{C}_{20}$ and five polyunsaturated fatty acids: $\mathrm{C}_{14: 1}, \mathrm{C}_{16: 1}, \mathrm{C}_{18: 1}$,

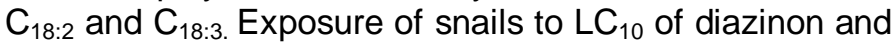
profenofos induced remarkable alterations in the percentages of fatty acids contributions in their tissues. Thus, the area percentages of some fatty acid in snails' tissues were significantly elevated than those of the control group, e.g. the saturated fatty acids $C_{12: 0}, C_{14: 0}$, $\mathrm{C}_{17: 0}$ and $\mathrm{C}_{18: 0}$, while the profile of sex fatty acids were significantly reduced, three are saturated $\mathrm{C}_{8: 0}, \mathrm{C}_{9: 0}$ and $\mathrm{C}_{15: 0}$ and the others are polyunsaturated $\mathrm{C}_{18: 1}, \mathrm{C}_{18: 2}$ and $\mathrm{C}_{18: 3}$. Furthermore, one saturated $\left(\mathrm{C}_{16: 0}\right)$ and two polyunsaturated $\left(\mathrm{C}_{14: 1}\right.$ and $\left.\mathrm{C}_{16: 1}\right)$ fatty acids were not detected in tissues of snails treated with diazinon and profenofos. The current data indicate that, the mean 
Table 4. Dice's similarity coefficient $\left({ }^{*} S\right)$ of the protein profile bands between control snails and snails treated for 4 weeks with Basudin and Selecron (pesticides).

\begin{tabular}{lccc}
\hline Parameter & Control & Basudin & Selecron \\
\hline Control & 1 & 0.28 & 0.22 \\
Basudin & 0.28 & 1 & 0.33 \\
Selecron & 0.22 & 0.33 & 1 \\
\hline
\end{tabular}

${ }^{*} \mathrm{~S}=2 \mathrm{a} / 2 \mathrm{a}+\mathrm{b}+\mathrm{c}$, where: $\mathrm{a}=$ the number of shared bands between two individuals; $b=$ the bands present in the 1 st and not in the $2 n d$, and $c=$ the bands present in the 2 nd and not in the 1 st.

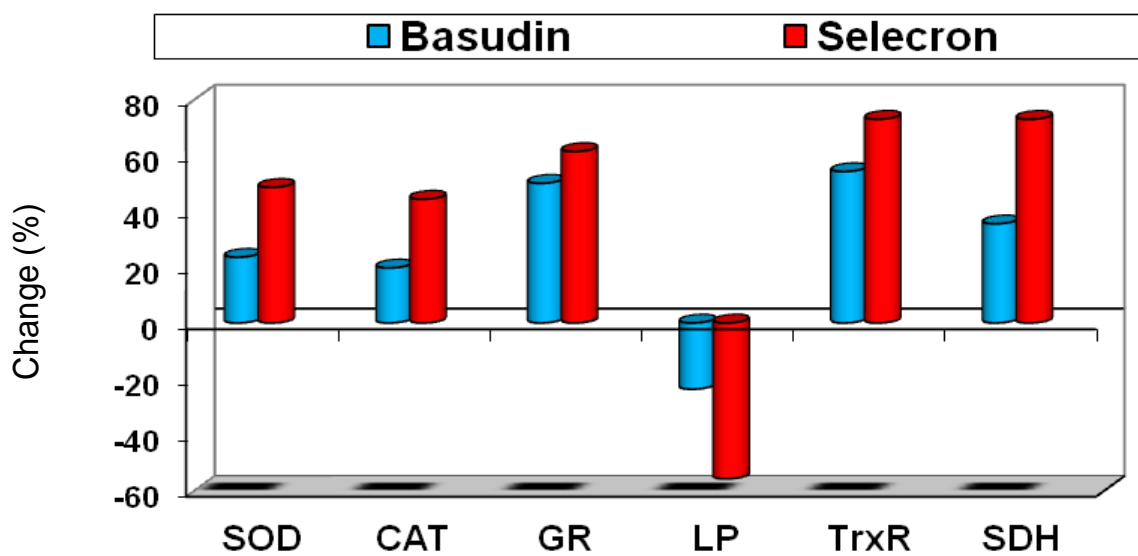

Figure 2. Changes (\%) of some antioxidant enzymes, (thioredoxin reductase (TrxR), sorbitol dehydrogenase ( $\mathrm{SDH}$ ), superoxide dismutase (SOD), catalase (CAT), glutathione reductase (GR) and lipid peroxides(LP) in soft tissues of Biomphalaria alexandrina exposed to $L_{10}$ of Basudin and Selecron (pesticides) for 4 weeks.

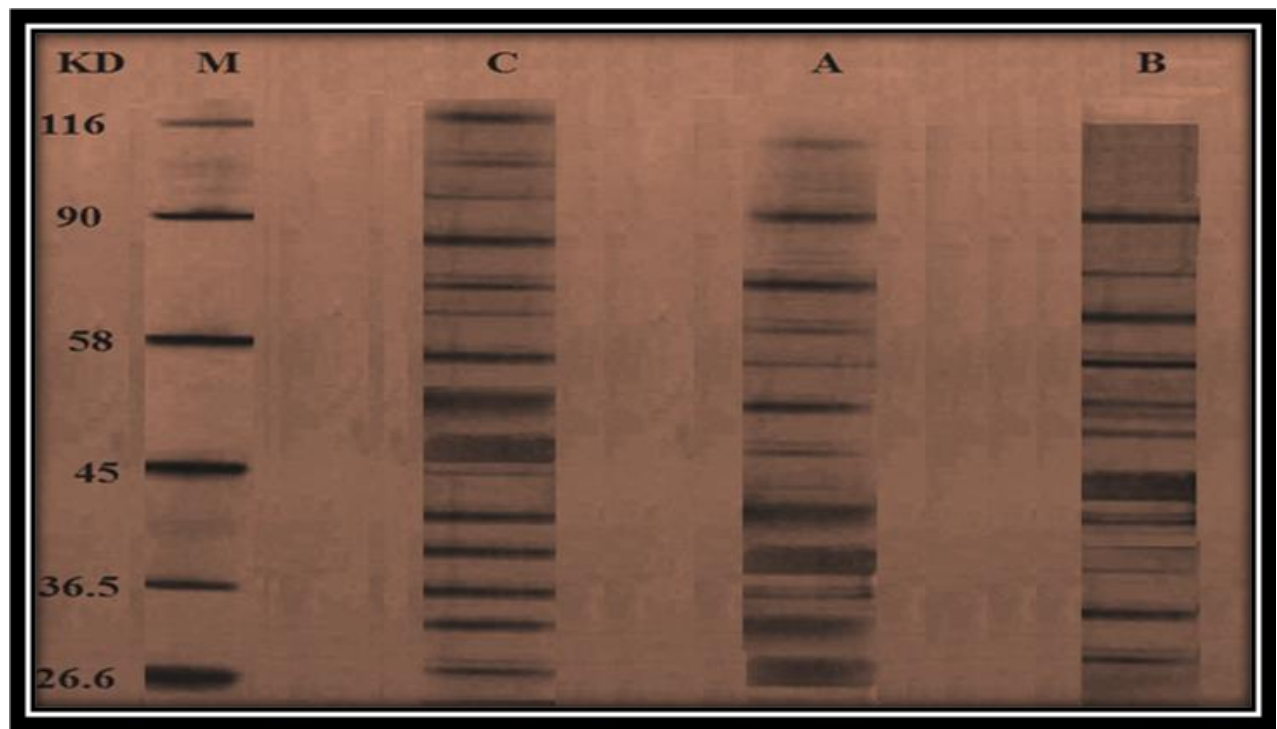

Figure 3. Tissues protein fractionation of Biomphalaria alexandrina snails treated with Basudin and Selecron (pesticides) for 4 weeks. $A=$ Snail treated with 1.9 ppm Basudin pesticide, $B=$ Snails treated with $0.75 \mathrm{ppm}$ Selecron pesticide, $C=$ Cotrol and $M=$ Marker $\mathrm{KDa}$. 
Table 5. Antioxidant enzymes in tissues of Biomphalaria alexandrina snails post 4 weeks of continuous exposure to Basudin and Selecron (pesticides).

\begin{tabular}{|c|c|c|c|c|c|}
\hline \multirow{2}{*}{ Parameter } & \multirow{2}{*}{$\begin{array}{c}\text { Control } \\
\text { Mean } \pm S D \\
\end{array}$} & \multicolumn{2}{|c|}{1.9 ppm Basudin } & \multicolumn{2}{|c|}{$0.75 \mathrm{ppm}$ Selecron } \\
\hline & & Mean $\pm S D$ & Change (\%) & Mean $\pm S D$ & Change (\%) \\
\hline Superoxide dismutase (SOD) & $0.068 \pm 0.12$ & $0.052 \pm 0.05^{*}$ & 23.53 & $0.035 \pm 0.08^{* *}$ & 48.53 \\
\hline Catalase (CAT) & $77.2 \pm 4.3$ & $62 \pm 5.8^{*}$ & 19.69 & $43+2.3 \pm 0.4^{* *}$ & 44.30 \\
\hline Glutathione reductase (GR) & $0.44 \pm 0.6^{\mathrm{a}}$ & $0.22 \pm 0.3^{\star \star}$ & 50 & $0.17 \pm 0.5^{*}$ & 61.36 \\
\hline Lipid peroxides (LP) & $10.4 \pm 0.45$ & $13.8 \pm 0.84^{*}$ & -23.69 & $16.2 \pm 0.66^{\star \star}$ & -55.77 \\
\hline Thioredoxin reductase $(\operatorname{Tr} x \mathrm{R})$ & $0.48 \pm 0.08$ & $0.22 \pm 0.04^{\star^{*}}$ & 54.17 & $0.13 \pm 0.05^{\star \star \star}$ & 72.92 \\
\hline Sorbitol dehydrogenase (SDH) & $0.031 \pm 0.07$ & $0.020 \pm 0.062^{\star *}$ & 35.48 & $0.0084 \pm 0.043^{\star \star \star}$ & 72.90 \\
\hline
\end{tabular}

${ }^{*} \mathrm{P}<0.05 ;{ }^{* \star} \mathrm{P}<0.01 ;{ }^{* * *} \mathrm{P}<0.001$. Values are means $\pm S D$ of six replicates. Values are $\mu \mathrm{mol} / \mathrm{min} / \mathrm{mg}$ protein while lipid peroxide is in $\mu \mathrm{g} / \mathrm{g}$ tissue.

Table 6. Area percent of fatty acid contributions in tissues of $B$. alexandrina snails treated for 4 weeks with Basudin and Selecron (pesticides).

\begin{tabular}{|c|c|c|c|}
\hline Fatty acid (\%) & Control & $\begin{array}{l}\text { Basudin } \\
1.9 \mathrm{ppm}\end{array}$ & $\begin{array}{l}\text { Selecron } \\
0.75 \text { ppm }\end{array}$ \\
\hline Caprylic $\left(\mathrm{C}_{8: 0}\right)$ & $0.62 \pm 0.22$ & $0.25 \pm 0.01^{* * *}$ & $0.19 \pm 0.02^{* * *}$ \\
\hline Pelargonic $\left(\mathrm{C}_{9: 0}\right)$ & $0.12 \pm 0.06$ & $0.085 \pm 0.003^{\star \star \star}$ & $0.070 \pm 0.001^{\star \star \star}$ \\
\hline Capric $\left(\mathrm{C}_{10: 0}\right)$ & $0.14 \pm 0.03$ & $0.31 \pm 0.05^{\star * *}$ & $0.148 \pm 0.06^{* * *}$ \\
\hline Louric $\left(\mathrm{C}_{12: 0}\right)$ & $0.27 \pm 0.01$ & 8. $00 \pm 1.33^{\star * *}$ & $3.00 \pm 0.19^{\star * *}$ \\
\hline Myristic $\left(\mathrm{C}_{14: 0}\right)$ & $0.23 \pm 0.11$ & $5.100 \pm 0.67^{\star \star \star}$ & $5.0 \pm 1.00^{\wedge \wedge \wedge}$ \\
\hline Myristolic $\left(\mathrm{C}_{14: 1}\right)$ & $3.97 \pm 0.50$ & N.D & N.D \\
\hline Pentadecylic $\left(\mathrm{C}_{15: 0}\right)$ & $10.90 \pm 8.22$ & $2.90 \pm 0.56$ *** & $2.50 \pm 0.45^{\star \star \star}$ \\
\hline Palmatic $\mathrm{C}_{16: 0}$ & $19.65 \pm 4.80$ & N.D & N.D \\
\hline Palmitoleic $\mathrm{C}_{16: 1}$ ) & $8.47 \pm 0.79$ & N.D & N.D \\
\hline Margaric $\left(\mathrm{C}_{17: 0}\right)$ & $27.78 \pm 2.38$ & $40.23 \pm 2.90^{* * *}$ & $44.0 \pm 4.90^{* \star *}$ \\
\hline Stearic $\left(\mathrm{C}_{18: 0}\right)$ & $2.753 \pm 0.20$ & $5.52 \pm 1.88^{\star * *}$ & $7.10 \pm 0.90^{\star * \star}$ \\
\hline Oleic $\left(\mathrm{C}_{18: 1}\right)$ & $11.60 \pm 3.10$ & $3.66 \pm 0.22^{\star \star *}$ & $2.092 \pm 0.80^{\star * *}$ \\
\hline Lenoleic $\left(\mathrm{C}_{18: 2}\right)$ & $11.89 \pm 2.18$ & $5.40 \pm 1.10^{\star \star \star}$ & $11.00 \pm 1.90^{* * *}$ \\
\hline Lenolenic $\left(\mathrm{C}_{18: 3}\right)$ & $9.08 \pm 1.3$ & $3.00 \pm 0.80^{\star \star \star}$ & $2.30 \pm 0.55^{\star \star \star}$ \\
\hline Arachidonic $\left(\mathrm{C}_{20: 0}\right)$ & $5.98 \pm 0.80$ & $1.50 \pm 0.40^{* * *}$ & $0.10 \pm 0.006^{* * 9}$ \\
\hline Chain length ${ }^{\mathrm{x}}$ & $14.43 \pm 0.58$ & $10.99 \pm 0.99^{\star *}$ & $10.67 \pm 0.87^{* *}$ \\
\hline $\mathrm{USI}^{\mathrm{XX}}$ & $64.16 \pm 11.58^{a}$ & $44.90 \pm 12.30^{\star *}$ & $45.45 \pm 10.10^{* *}$ \\
\hline Total lipid & $0.45 \pm 0.01^{\mathrm{a}}$ & $0.09 \pm 0.002^{* *}$ & $0.09 \pm 0.003^{\star *}$ \\
\hline
\end{tabular}

${ }^{* *} \mathrm{P}<0.01 ;{ }^{* *} \mathrm{P}<0.001$. Values are means $\pm S D$ of six replicates. Values are expressed as moles percentages. Total lipid is expressed in $\mathrm{mg} / \mathrm{dl}$. Mean chain length ${ }^{X}$ : is defined as $\sum \mathrm{fi} \mathrm{ci}$, where $\mathrm{fi}$ is the mole fraction and $\mathrm{ci}$ is the number of carbon atoms of fatty acids. USI ${ }^{\times x}$ Unsaturation index and is defined by $\Sigma \mathrm{mi} n \mathrm{ni}$, where $\mathrm{mi}$ is the mole percentage and $\mathrm{ni}$ is the number of carbon -carbon double bonds of fatty acids.

chain lengths, unsaturation index and total lipid content were significantly reduced in tissues of $B$. alexandrina snails post pesticides treatments.

\section{DISCUSSION}

At present, control of the snail intermediate host of schistosomiasis by molluscicides is the best available method for effective and quick reduction of the disease transmission. Although there are many chemicals applied to control the snails' hosts of schistosomiasis, the ideal molluscicide had not yet been found (WHO, 1965). This makes the search for an acceptable new molluscicidal agent an essential target.

The present results showed profenofos to be more toxic to the snails than diazinon. This data agreed with Youssef (2010) observations on the toxicity of profenofos 
and diazinon to $B$. alexandrina snails. This difference in the efficacy of the tested pesticides against the snails could be due to the differences in their pathways of penetration inside the treated organism, as well to differences in their mode of action on the target organ (Etges and Guilberton, 1966).

The survival rates of adult $B$. alexandrina snails were markedly reduced post continuous exposure for 4 weeks to the sublethal concentrations of the present tested pesticides (Profenofos and Diazinon). Similar observations were noticed by Sharaf El-Din et al. (2004) using the herbicide dithiopyridine carboxylic acid, by Mahmoud (2006) using the insecticides: regent and mimic, by Abdel Raouf (2007) using the insecticide, by Esmaeil (2009) using the fungicide. However, Serrano et al. (2002) reported that Biomphalaria glabrata snails exposed to hydrocortisone had long survival periods than control group.

The reproductive rate $\left(R_{0}\right)$ and fecundity $\left(M_{x}\right)$ of adult $B$. alexandrina snails, in the present study, were sharply decreased by their exposure for 4 weeks to profenofos and diazinon. The reduction of these parameters for treated snails could be attributed to their high mortality rates, different periods of ceasing oviposition during the experimental period and deteriorations in the activities of antioxidant enzymes (SOD, CAT, GR, peroxidation, TrxR and SDH), fatty acid profile and protein patterns in snails' tissues which means a damage to the snails' cells that interrupt their physiological activities, suppressing their oviposition $\left(M_{x}\right)$ and the reproductive rate $\left(R_{0}\right)$ (El-Ansary et al., 2001; Ibrahim, 2006; Youssef, 2010).

The present results indicated that $\mathrm{LC}_{10}$ of diazinon (1.9 ppm) and profenofos ( $0.75 \mathrm{ppm})$ had qualitative and quantitative effects on the protein patterns of snails' soft tissues. The electrophoretic pattern of the native proteins revealed difference in the number and molecular weights of protein bands compared to control snails. These differences indicated that the tested pesticides caused intensive molluscicidal effects that induced fractionation of the native protein. This report was previously recorded by Bakry et al. (2011) who found that deltamethrin and malathion had qualitative and quantitative effect on the protein patterns of Helisoma duryi snails. Furthermore, treated groups with the present pesticides showed less number of protein bands indicating that the pesticides were thought to induce damage for these snails. Protein changes due to snail treatment with plant extracts were previously detected by many authors (Rawi et al., 1993; Aly et al., 2004; El-Sayed, 2006). Accordingly, the fractionation of native proteins into bands different from that of the control may be attributed to changes that occurred in DNA of the treated snails (El-Sayed, 2006).

The present study showed a significant reduction in SOD, CAT, and GR with a significant increase in lipid peroxidation activities in the tissue of snails treated with diazinon and profenofos. Since the complex mechanism of lipid peroxidation is known to require the participation of highly reactive oxygen and other reactive metabolites in the chain of biochemical reaction, thus, in any part of the body where these free radicals are produced, lipid peroxides are in turn increased. Such phenomenon was previously reported by El-Rigal et al. (2006) and Botros et al. (2007).

At the same time, GSH is drastically depleted in the tissue such depletion is critical, as shown by the increased cytotoxicity of $\mathrm{H}_{2} \mathrm{O}_{2}$ in endothelial cells, as a result of inhibition of glutathione reductase, which keeps glutathione in its reduced state (El-Rigal et al., 2006).

These results are in a good agreement with results of Mittelstaedt et al. (2004) who suggested that, nuclei and mitochondria acted as major targets of toxic action, probably by increasing the generation of free radicals, lipid peroxidation and DNA adducts formation.

Thioredoxin systems, involving redox active thioredoxins and thioredoxin reductases, sustain a number of important thioredoxin-dependent pathways. These redox active proteins support several processes crucial for cell function, cell proliferation, antioxidant defense and redoxregulated signaling cascades (Elias, 2009). Our data showed a significant statistical inhibition of tissue enzyme TrxR in treated snails as compared to the normal control group, indicating cellular damage mainly due to leakage of this enzyme from tissue into the hemolymph stream as a result of liberation of free radical and oxidative process (Soliman et al., 2007).

Quantitative analysis of the present study revealed the presence of, 15 different fatty acids detected in treated $B$. alexandrina with tested pesticides. In general, the major components of the FFA fraction were $\mathrm{C}_{15: 0}, \mathrm{C}_{16: 0}, \mathrm{C}_{16: 1}$, $\mathrm{C}_{17: 0}, \mathrm{C}_{18: 1}, \mathrm{C}_{18: 2}, \mathrm{C}_{18: 3}$ and $\mathrm{C}_{20: 0}$. The present results are concerned with marked depletion in the level of long chain fatty acids $\left(\mathrm{C}_{15: 0,}, \mathrm{C}_{18: 1}, \mathrm{C}_{18: 2,}, \mathrm{C}_{18: 3}\right.$ and $\left.\mathrm{C}_{20: 0}\right)$, while enhancement of $\mathrm{C}_{17: 0}$ and $\mathrm{C}_{18: 0}$ in either saturated or unsaturated $B$. alexandrina snail post pesticide treatments. Moreover, depletion of some long chain and short chain fatty acids may be explained on the basis that reduction in rates of glucose metabolism in the snails was balanced through the stimulation of triglyceride hydrolysis and fatty acid oxidation (Ahmed and El-Ansary, 1994; Leo et al., 2010). These may be explained on the basis that, these effective pesticides could have immunostimulatory effect through induced lysine amino acids which is considered as a critical importance in inducing parasite killing by hemocytes of molluscicides-treated snails (Soliman et al., 2007).

Intermediate host $B$. alexandrina snail was shown to have high contribution of poly-unsaturated fatty acids (PUFA) $\mathrm{C}_{18: 1}, \mathrm{C}_{18: 2}$ and $\mathrm{C}_{18: 3}$. These high contributions of PUFA in $B$. alexandrina may be explained by the presence of considerable elongation and instauration activities in the snail. Treatment of the intermediate host with the pesticides produced obvious reduction in these 
fatty acid contributions which is considered as index of disturbances in elongation, instauration process of fatty acid and inhibition of activity of intermediate host (Abdel Raouf, 2007). In addition, $\mathrm{C}_{18: 2}$ (linoleic acid) availability is considered as an aspect of biochemical adaptation. Being in an environment or medium rich with linoleic acid may be considered as a prerequisite for the schistosoma parasite to be transformed into Cercariae more efficient for penetration and development in the final host (Soliman et al., 2007; Randall et al., 1992; Marcel et al., 1994) suggested that, polyunsaturated fatty acids and prostaglandins play a role in the physiological response to hypoxia. Reduced level of these contributions $\left(\mathrm{C}_{18: 1}\right.$, $\mathrm{C}_{18: 2}, \mathrm{C}_{18: 3}$ ) and lower unstaturation index (USI) in snailtreated plants may be important to un-adapt condition that prevent aerobic-anaerobic transition induced by the schistosoma parasite.

It is well known that, fatty acid pattern of the molluscan hosts is of great importance for developing parasite; in this concern, Fukushima et al. (1993) reported that arachidonic acid $\left(\mathrm{C}_{20: 0}\right)$ metabolized to prostaglandin $\mathrm{E}_{2}$ $\left(\mathrm{PGE}_{2}\right)$ by intermediate host $B$. alexandrina snail. $P \mathrm{PE}_{2}$ is known to suppress the functions of mononuclear cells and immune system of the intermediate host to enable the development of parasite inside the host. Low percentage contribution of arachidonic acid post different treatment of pesticides leads to decrease in the level of $\mathrm{PGE}_{2}$ and enhancement in immune system of the host that in turn overcome parasite development.

In conclusion, treatment of $B$. alexandrina snails with sublethal concentrations of the two pesticides were effective in altering the fatty acids profile of this snail species which could contribute to the disturbance in biochemical mechanisms and impairment of snail egg laying capacity.

\section{Conclusions}

Aquatic environments can be contaminated with residues of diazinon and profenofos pesticides that result from their application in agricultural activities having toxic effects on $B$. alexandrina snails. It may be concluded that exposure of $B$. alexandrina snails to low concentrations of diazinon and profenofos led to depletion of the fatty acid profile and antioxidant enzymes in tissues of these snails. Changes in physiological activities of snails are mostly responsible for reduction of egg production and the high rate of mortality in treated snails.

\section{REFERENCES}

Abdel Kader AE, Sharaf El-Din AT (2005). Effect of the pesticides Carbofuran (carbamate) and Profenophos (organophosphorus) on Biomphalaria alexandrina and on its infection with Schistosoma mansoni miracidia, Egypt. J. Schist. Infect. Endem. Dis. 27:71-83.
Abdel Raouf HA (2007). Comparative studies of the effect of certain synthetic compounds and a plant molluscicide on the fresh water snail, Biomphalaria alexandrina and some of its larval parasites. M.Sc. Thesis, Zoology Department, Fac. Sci., Al-Azhar Univ., Egypt.

Ahmed SA, El -Ansary AK (1994). Observation on use of dursban as a molluscicide on some biochemical processes in Biomphalaria alexandrina snails. Egypt. J. Pharm. Sci. 35:539-552.

Alahyary P, Ilkhani M, Fathy F (2008). The potential toxicity of Diazinon onphysiological factors in male rabbits, Pak. J. Biol. Sci. 11(1):127130.

Alam M, Ghiasuddin, Sadat A, muhammd N, Khan AA, Siddiqui BS (2012). Evaluation of Viburnum grandiflorum for its in-vitro pharmacological screening. Afr. J. Pharm. Pharmacol. 6(22):1606-1610.

Al-Saleh IA (1994). Pesticides: a review article. J. Environ. Pathol. Toxicol. Oncol. 13:151-161.

Aly SA, Aly SAHF, Saba-El-Rigal N, Sammou REM (2004). Induced changes in biochemical parameters of the molluscan tissues noninfected using two potent plants molluscicides. J. Egypt. Soc. Parasitol. 34:527-542.

Arnér E, Holmgren A (2000). "Physiological functions of thioredoxin and thioredoxin reductase". Eur. J. Biochem. 267:6102-6109.

Asgarpanah J, Ramezanloo F (2012). Chemistry, pharmacology and medicinal properties of Peganum harmala L. Afr. J. Pharm. Pharmacol. 6(22):1573-1580.

Bakry FA, Hasheesh WS, Hamdi SAH (2011). Biological, biochemical, and molecular parameters of Helisoma duryi snails exposed to the pesticides Malathion and Deltamethrin. Pestic. Biochem. Physiol. 101:86-92.

Bergmeryer HU (1974). Sorbitol dehydrogenase. In: Methods of Enzymatic Analysis. $3^{\text {rd }}$ Edn., Verly Chemie, Weinheim , Academic Press, London, 569-573.

Botros SS, Mahmoud MR, Moussa MM, Nosseir MM (2007). Immunohistopathological and biochemical changes in Schistosoma mansoni-infected mice treated with artemether. J. Infect. 55:47-477.

Buge JA, Aust SD (1978). Microsomal lipid per oxidation. Methods Enzymol. 52:302-310.

Cabaj M, Toman T, Adamkovičová M, Massányi P, Šiška B, Lukáč N, Golian J (2010). Structural changes in the rat testis caused by diazinon and selenium. Potravinarstvo 4:8-16.

Das PG, Shaik PA, Jamil K (2006). Cytotoxicity, genotoxicity induced by the pesticide profenofos on cultured human peripheral blood lymphocytes, Drug Chem. Toxicol. 3:313-322.

De Leo M, Saltos MBV, Puente BFN, De Tommasi N, Braca A (2010). Sesquiterpenes and diterpenes from Ambrosia arborescens. Phytochem. 71:804-809.

Dice LR (1945). Measures of the amount of ecological association between species. Ecology 26:297-302.

El-Ansary A, Sammour EM, Soliman MS, Gawish FA (2001). In vivo attenuation of schistosome cercarial development and disturbance of egg-laying capacity in Biomphalaria alexandrina using sublethal concentrations of plant molluscicides. J. Egypt. Soc. Parasitol. 31(3):657-669.

Elias ASJ (2009). Focus on mammalian thioredoxin reductases Important seleno proteins with versatile functions. Biochimica and Biophysica Acta 1790:495-526

El-Rigal NS, Aly SA, Rizk, MZ, Said AA (2006). Effect of Ailanthus altissima and Ziziphus spina Christi extracts on some hepatic marker enzymes and antioxidants in Shistosoma mansoni infected mice. Pol. J. Food Nutr. Sci. 15/56:199-206.

El-Sayed KA (2006). Effect of the plant Cupressus macro-carpa (Cupressacea) on some haematological and Biochemical parameters of Biomphalaria alexandrina snails, J. Egypt. Soc. Parasitol. 36:911924

Erden M, Bor NM (1984). Changes in reduced glutathione, glutathione reductase and glutathione peroxidase after radiation in guinea pigs, Biochem. Med. 31:217-227.

Esmaeil EA (2009). Biological and irnmunological studies on Biomphalaria alexandrina snails, the intermediate host of Schistosoma mansoni in Egypt. Ph.D. Thesis, Fac. Sci., Menufia Univ., Egypt. 
Etges FJ, Guilberton DF (1966). Repellent action of some chemical molluscicides and 504 schistosome vector snails, Am. J. Trop. Med. Hyg. 15:618-624.

Fukushima T, Isobe A, Hojo N, Shiwaku K, Yamane Y, Torii M (1993). The metabolism of arachidonic acid to prostaglandin E2 in Plerocercoids of Spirometra erinacei. Parasit. Res. 79:634-638.

Fried B, Rao KS, Sherma J (1991). Fatty acid composition of Biomphlaria Glabrata (Gastropoda : Planorbidae) Fed hens egg yolk versus leaf lettuce. Comp. Biochem. Physiol. 39:1-2.

Goldstein A (1964). Biostatistics: An introductory text. Macmillan, New York, 51.

Higgs MH, Sherma J, Fried B (1990). Natural lipids in the digestive gand-gonad complex of Biomphalaria glabrata snails, fed lettuce vs hens egg yolk determined by quantitative TLC-densitometry. J. Planar Chromatogr. 3:38-41.

Ibrahim MM (2006). Energy allocation patterns in Biomphalaria alexandrina snails in response to cadmium exposure and Schistosoma mansoni infection. Exp. parasitol. 122:31-36.

Laemmli KU (1970). Cleavage of structural proteins during the assembly of the head of bacteriophage T4. Nature 227:680-685.

Litchfield JT, WiLcoxon F (1949). A simplified method of evaluating dose-effect experiments, J. Pharmacol. Exp. Therap. 96:99-113.

Mahmoud MB (2006). Biological and histological impacts of the insecticides Regent and Mimic on Biomphalaria alexandrina snails. Egypt. J. Zool. 46:11-21.

Marchat L, Loiseau PM, Pous C, Petek F (1994). Isoenzymatic diagnosis of filariae: a method for separation of lactate dehydrogenase isoenzymes from Molinema dessetae (Nematoda: Filarioidea). Comp. J. Physiol. Biochem. 109:451-457.

Marcel TM, Van Raaij EB, Maaike CN, Hans Z, Guido EEJM (1994). Energy status and free fatty acid patterns in tissues of common carp(Cyprinus carpio L.) and rainbow trout (Oncorhynchus mykiss L.) during severe oxygen restriction. Comp. Biochem. Physiol. 109A:755-767.

Mittelstaedt RA, Mei N, Webb PJ, Shaddock JG, Dobrovolsky VN, MacGarrity LJ, Morris SM, Chen T, Beland FA, Greenlees KJ, HeXich RH (2004). Genotoxicity of malachite green and leucomalachite green in female Big Blue B6C3F1 mice. Mutation Res. 561:127-138.

Monhanty JG, Jonathan S, Jaffe E, Edaward S, Donald GR (1997). A highly sensitive fluorescent microassay of $\mathrm{H}_{2} \mathrm{O}_{2}$ release from activated human leukocytes using a dihydroxphenoxazine derivative. $J$. Immunol. Methods 202:133-137.

Morris LJ (1962). Separation of higher fatty acid isomerase and by thin layer chromatography. Chem. Ind. 1238-1240.

Nasri S, Anoush M, Khatami N (2012). Evaluation of analgesic and antiinflammatory effects of fresh onion juice in experimental animals. Afr. J. Pharm. Pharmacol. 6(23):1679-1684.
Nishikimi M, Appaji N, Yagi K (1972). The occurrence of superoxide anion in the reaction of reduced phenazine methosulfate and molecular oxygen. Biochem. Biophys. Res. Commun. 46:849-854.

Pellegrino J, Goncalves MGR (1965). A simple method for collecting egg clutches of Biomphalaria glabrata (Australorbis glabratus) and for rearing newly hatched snails, J. Parasitol. 51:10-14.

Randall DJ, Mekenzie DJ, Abrami G, Bondiolotti GP, Natiello F, Bolis L, Agradi $E$ (1992). Effect of diet on responses to hypoxia in sturgeon ( Acipenser naccarii). J. Exp. Biol. 170:113-125.

Rawi SM, El-Gindy HI, Abd-Kader A (1993). The effect of some molluscicides on total protein, albumin, globulin and total lipid of the snail Biomphalaria alexandrina, Bull. Fac. Sci. Cairo Univ. 61:87-101.

Rawi SM, El-Gindy HI, Abdel Kader A (1994). The effect of some fresh water pollutants on the survival and egg production of the snail $B$. alexandrina, J. Egypt. Ger. Zool. 13:273-288.

Serrano DR, Zanotti-Magalhaes EM, Magalhaes LA, Carvalho JE (2002). Influencia da hidrocortisona do Schistosoma mansoni em Biomphalaria glabrata. Rev. Soc. Bras. Med. Trop. 35:149-53.

Sharaf El-Din AT, El-Sayed KA, Mahmoud MB (2004). Effect of Dithiopyridine carboxylic acid (Herbicide) on Biomphalaria alexandrina snails and the free larval stages of Schistosoma mansoni. J. Egypt. Ger Soc. Zool. 43(D):215-29.

Soliman KM, Mohamed AM, Metwally NS (2007). Attenuation of some metabolic deteriotions induced by diabetes mellitus using carnosine. J. Applied Sci. 7(16):2252-2260.

Tomlin CDS (1997). The pesticide manual, 11th Ed (ISBN 190139611 8). British Crop Protection Council, UK.

Van Cong N, Phuong NT, Bayley M (2006). Sensitivity of brain cholinesterase activity to Diazinon (Basudin 50EC) and Fenobucarb (Bassa 50EC) insecticides in the air-breathing fish Channa striata (Bolch, 1793). J. Environ. Toxicol. Chem. 25:1418-1425.

World Health Organization (1965). Molluscicide screening and evaluation, Bull. WHO 33, 567-581.

Youssef AA (2010). Studies on the impact of some pesticides and Egyptian plants on some biological and physiological parameters of Biomphalaria alexandrina snails and their susceptibility to infection with Schistosoma mansoni miracidia. M.Sc. Thesis, Faculty of science, Al-Azhar University, Egypt.

Zollner N, Kirsch K (1962). Total lipids colorimetric method. Z. ges. Exp. Med. 135:545. 